\title{
High Contrast Ratio and Rapid Switching Electrochromic Polymeric Films Based on 4-(Dimethylamino)triphenylamine-Functionalized Aromatic Polyamides
}

\author{
Sheng-Huei Hsiao, ${ }^{* \dagger}$ Guey-Sheng Liou, ${ }^{*}, *$ Yi-Chun Kung, ${ }^{\dagger}$ and Hung-Ju Yen ${ }^{*}$ \\ High Performance Polymers Laboratory, Department of Chemical Engineering, Tatung University, \\ Taipei, Taiwan, and Functional Polymeric Materials Laboratory, Institute of Polymer Science and \\ Engineering, National Taiwan University, Taipei, Taiwan
}

Received November 1, 2007; Revised Manuscript Received February 2, 2008

\begin{abstract}
A series of electroactive aromatic polyamides with 4-(dimethylamino)triphenylamine [(NMe $\left.)_{2}\right) \mathrm{TPA}^{-}$ units in the backbone were prepared from a newly synthesized diamine monomer, 4,4'-diamino-4" amino)triphenylamine, and various aromatic dicarboxylic acids via the phophorylation polyamidation reaction. These polyamides are readily soluble in many organic solvents and can be solution-cast into tough and amorphous films. They had useful levels of thermal stability associated with relatively high glass-transition temperatures $\left(277-298{ }^{\circ} \mathrm{C}\right), 10 \%$ weight loss temperatures in excess of $500{ }^{\circ} \mathrm{C}$, and char yields at $800{ }^{\circ} \mathrm{C}$ in nitrogen higher than $67 \%$. The polymer films showed reversible electrochemical oxidation accompanied by strong color changes with high coloration efficiency, high contrast ratio, and rapid switching time. The optical transmittance change $(\Delta \% \mathrm{~T})$ at $640 \mathrm{~nm}$ between the neutral state and the fully oxidized state is up to $88 \%$, and the coloration efficiency is as high as ca. $261 \mathrm{~cm}^{2} / \mathrm{C}$ with high optical density change $(\delta \mathrm{OD})$ up to 0.94 . The polymers also displayed low ionization potentials as a result of their $\left(\mathrm{NMe}_{2}\right) \mathrm{TPA}$ moieties. Cyclic voltammograms of the polyamide films on the indium - tin oxide (ITO)-coated glass substrate exhibited a pair of reversible oxidation waves with very low onset potential of $0.35 \mathrm{~V}$ ( $\mathrm{vs} \mathrm{Ag} / \mathrm{AgCl}$ ) in acetonitrile solution.
\end{abstract}

\section{Introduction}

Electrochromism is known as the reversible change in optical absorption or transmittance upon redox switching. ${ }^{1}$ This interesting property led to the development of many technological applications such as automatic antiglazing mirror, smart windows, electrochromic displays, and chameleon materials. ${ }^{2}$ Many different classes of electrochromic materials, such as organic systems, e.g., bipyridium salt (also known as viologens), ${ }^{3}$ electroactive conducting polymers (e.g., polyanilines, ${ }^{4}$ polythiophenes, ${ }^{5}$ and polypyrroles), ${ }^{6}$ as well as inorganic systems based on transition metal oxides (e.g., $\left.\mathrm{WO}_{3}\right){ }^{7}$ have been described. Conducting or conjugated polymers have been found to be more promising as electrochromic materials because of their better stability, faster switching speeds, and easy processing compared to the inorganic electrochromic materials, but the most exciting properties are the display of multiple colors with the same material while switching between their different redox states, ${ }^{8}$ and fine-tuning of the color transition through chemical structure modification of the conjugated backbone. ${ }^{9,10}$ Considerable effort in the Reynolds group has been made on the understanding and the tailoring of electrochromic properties in conducting polymers such as poly(3,4-alkylenedioxythiophene $) s^{5}$ and poly(3,4-alkylenedioxypyrrole) $s^{6}$ and their derivatives.

Triarylamine derivatives are well-known for photo and electroactive properties that find optoelectronic applications as photoconductors, hole transporters, and light emitters. ${ }^{11}$ Triarylamines can be easily oxidized to form stable radical cations, and the oxidation process is always associated with a noticeable change of coloration. Thus, many triarylamine-based electrochromic polymers have been reported in the literature. ${ }^{12}$ In recent years, we have developed a number of high-performance

\footnotetext{
* To whom all correspondence should be addressed. E-mail: shhsiao@ ttu.edu.tw (S.-H.H.); gsliou@ @ ntu.edu.tw (G.-S.L.).

Tatung University.

* National Taiwan University.
}

polymers (e.g., aromatic polyamides and polyimides) carrying the triphenylamine (TPA) unit as an electrochromic functional moiety. ${ }^{13}$ Our strategy was to synthesize the TPA-containing monomers such as diamines and dicarboxylic acids that were then reacted with the corresponding comonomers through conventional polycondensation techniques. The obtained polymers possessed characteristically high molecular weights and high thermal stability. Because of the incorporation of packingdisruptive, propeller-shaped TPA units along the polymer backbone, most of these polymers exhibited good solubility in polar organic solvents. They may form uniform, transparent amorphous thin films by solution-casting and spin-coating methods. This is advantageous for their ready fabrication of large-area thin-film devices.

In order to be useful for applications, electrochromic materials must exhibit long-term stability, rapid redox switching, and large changes in transmittance (large $\Delta \% \mathrm{~T}$ ) between their bleached and colored states. ${ }^{14}$ As an electrochromic functional moiety, the TPA unit has two basic properties: (1) the easy oxidizability of the nitrogen center and (2) its hole-transporting ability via the radical cation species. However, unsubstituted TPA undergoes coupling deprotonation to form tetraphenylbenzidine after the formation of the initial monocation radical. ${ }^{15}$ The oxidation potential and the $\pi-\pi^{*}$ bandgap of the product, generally called triaryldiamine, are different from that of the starting material. Therefore, the small concentration of the product may cause an unstable color change of the electrochromic material during redox switching. The formation of protons as byproduct may deteriorate the coloration efficiency of the electrochromic devices through undesirable side reactions. It has been well established that incorporation of electron-donating substituents such as methoxy group at the para position of TPA prevents the coupling reactions and affords stable radical cations. ${ }^{15,16}$ It has also been demonstrated that carbazole derivatives with dimethylamino $\left(\mathrm{NMe}_{2}\right)$ groups para to the carbazole nitrogen could afford quite stable radical cations in the first one-electron oxidation process and reasonably stable dication quinonedi- 
imines could also be generated by a second one-electron process. ${ }^{17}$ Therefore, we synthesized the diamine monomer, $4,4^{\prime}$ diamino-4"-(dimethylamino)triphenylamine [(NMe $)$ TPA-diamine; 2], and its derived aromatic polyamides containing electroactive TPA units with electron-donating $\mathrm{NMe}_{2}$ para substituted on the pendent phenyl ring. The $\mathrm{NMe}_{2}$ substituents are expected to reduce the oxidation potential and increase the electrochemical stability and electric conductivity of the polyamides. We anticipated that the electrochromic films prepared from the present polyamides would be very stable to multiple redox switching and exhibit enhanced optical response times. For a comparative study, some properties of the present polyamides will be compared with those of structurally related ones based on 4,4'-diamino-4"'-(diphenylamino)triphenylamine $\left[\left(\mathrm{NPh}_{2}\right) \mathrm{TPA}\right.$-diamine; $\left.\mathbf{2}^{\prime}\right]$ that has been reported previously. ${ }^{13 \mathrm{~b}}$

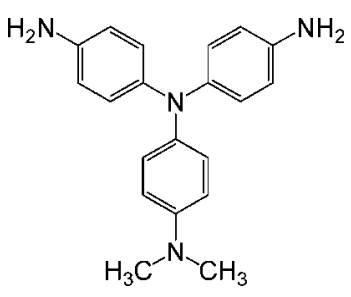

2

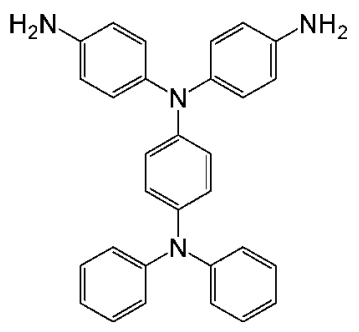

2'

\section{Experimental Section}

Materials. The $\left(\mathrm{NPh}_{2}\right) \mathrm{TPA}$-diamine $\mathbf{2}^{\prime}\left(\mathrm{mp} 245-248{ }^{\circ} \mathrm{C}\right)$ was synthesized according to a previously reported procedure. ${ }^{13 a}$ Commercially available aromatic dicarboxylic acids such as 1,4naphthalenedicarboxylic acid (3a), 4,4'-oxidibenzoic acid (3b), 4,4'sulfonyldibenzoic acid (3c), and 2,2'-bis(4-carboxyphenyl)hexafluoropropane (3d) were purchased from Tokyo Chemical Industry (TCI) Co. and used as received. Commercially obtained anhydrous calcium chloride $\left(\mathrm{CaCl}_{2}\right)$ was dried under vacuum at $180{ }^{\circ} \mathrm{C}$ for $8 \mathrm{~h}$. Tetrabutylammonium perchlorate (TBAP) (Acros) was recrystallized twice by ethyl acetate under nitrogen atmosphere and then dried in vacuo prior to use. All other reagents were used as received from commercial sources.

Monomer Synthesis. 4,4'-Dinitro-4"'-(dimethylamino)triphenylamine (1). To a solution of $6.81 \mathrm{~g}(0.05 \mathrm{~mol})$ of $N, N$-dimethyl- $p$ phenylenediamine and $14.11 \mathrm{~g}(0.1 \mathrm{~mol})$ of 4-fluoronitrobenzene in $100 \mathrm{~mL}$ of dried dimethyl sulfoxide (DMSO), $15.20 \mathrm{~g}(0.1 \mathrm{~mol})$ of dried cesium fluoride $(\mathrm{CsF})$ was added with stirring all at once, and the mixture was heated at $140{ }^{\circ} \mathrm{C}$ for $18 \mathrm{~h}$ under nitrogen atmosphere. The mixture was poured slowly into $800 \mathrm{~mL}$ of ethanol with stirring, and the precipitated compound was collected by filtration and washed thoroughly by ethanol and water. The product was filtered to afford $17.78 \mathrm{~g}$ (94\% in yield) of dark red crystals with a mp of $182-183{ }^{\circ} \mathrm{C}$ (by DSC at a scan rate of $2{ }^{\circ} \mathrm{C} / \mathrm{min}$ ). IR (KBr): $1577,1340 \mathrm{~cm}^{-1}$ ( $\mathrm{NO}_{2}$ stretch). ${ }^{1} \mathrm{H}$ NMR (DMSO- $d_{6}, \delta$, ppm): 2.95 (s, 6H, methyl), $6.81\left(\mathrm{~d}, 2 \mathrm{H}, \mathrm{H}_{\mathrm{d}}\right), 7.08\left(\mathrm{~d}, 2 \mathrm{H}, \mathrm{H}_{\mathrm{c}}\right.$ ), $7.17\left(\mathrm{~d}, 4 \mathrm{H}, \mathrm{H}_{\mathrm{b}}\right), 8.16\left(\mathrm{~d}, 4 \mathrm{H}, \mathrm{H}_{\mathrm{a}}\right) .{ }^{13} \mathrm{C}$ NMR (DMSO- $\left.d_{6}, \delta, \mathrm{ppm}\right)$ : 40.3 (methyl), $113.5\left(\mathrm{C}^{7}\right), 121.4\left(\mathrm{C}^{3}\right), 125.4\left(\mathrm{C}^{2}\right), 128.6\left(\mathrm{C}^{6}\right), 132.3$ $\left(\mathrm{C}^{5}\right), 141.4\left(\mathrm{C}^{1}\right), 149.3\left(\mathrm{C}^{8}\right), 151.8\left(\mathrm{C}^{4}\right)$. Anal. Calcd $(\%)$ for $\mathrm{C}_{20} \mathrm{H}_{18} \mathrm{~N}_{4} \mathrm{O}_{4}$ (378.38): C, 63.49; H, 4.79; N, 14.81. Found: C, 63.37; $\mathrm{H}, 4.85 ; \mathrm{N}, 14.75$.

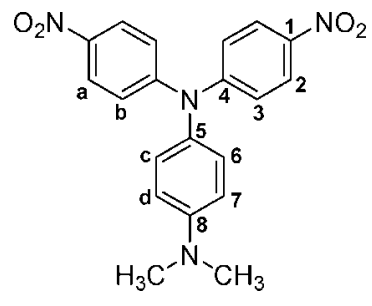

4,4'-Diamino-4" -(dimethylamino)triphenylamine (2). In a 100$\mathrm{mL}$ three-neck round-bottomed flask equipped with a stirring bar under nitrogen atmosphere, $7.56 \mathrm{~g}(0.01 \mathrm{~mol})$ of dinitro compound 1 and $0.1 \mathrm{~g}$ of $10 \% \mathrm{Pd} / \mathrm{C}$ were dispersed in $80 \mathrm{~mL}$ of ethanol. The suspension solution was heated to reflux, and $5 \mathrm{~mL}$ of hydrazine monohydrate was added slowly to the mixture. After a further $8 \mathrm{~h}$ of reflux, the solution was filtered to remove $\mathrm{Pd} / \mathrm{C}$, and the filtrate was cooled under nitrogen atmosphere to precipitate white crystals. The product was collected by filtration and dried in vacuo at $80{ }^{\circ} \mathrm{C}$ to give $5.42 \mathrm{~g}$ ( $85 \%$ in yield) of pale green crystals with a mp of $177-178{ }^{\circ} \mathrm{C}$ (by DSC). IR (KBr): $3417,3340 \mathrm{~cm}^{-1}$ (N-H stretch). ${ }^{1} \mathrm{H}$ NMR (DMSO- $d_{6}, \delta, \mathrm{ppm}$ ): 2.77 (s, 6H, methyl), 4.74 (s, 4H, $\left.-\mathrm{NH}_{2}\right), 6.47\left(\mathrm{~d}, 4 \mathrm{H}, \mathrm{H}_{\mathrm{a}}\right), 6.61\left(\mathrm{~d}, 2 \mathrm{H}, \mathrm{H}_{\mathrm{d}}\right), 6.65\left(\mathrm{~d}, 4 \mathrm{H}, \mathrm{H}_{\mathrm{b}}\right), 6.72$ $\left(\mathrm{d}, 2 \mathrm{H}, \mathrm{H}_{\mathrm{c}}\right.$ ). ${ }^{13} \mathrm{C}$ NMR (DMSO- $\left.d_{6}, \delta, \mathrm{ppm}\right): 40.8$ (methyl), 113.7 $\left(\mathrm{C}^{7}\right), 114.7\left(\mathrm{C}^{2}\right), 122.6\left(\mathrm{C}^{6}\right), 124.6\left(\mathrm{C}^{3}\right), 138.1\left(\mathrm{C}^{4}\right), 139.5\left(\mathrm{C}^{5}\right)$, $143.4\left(\mathrm{C}^{1}\right), 145.2\left(\mathrm{C}^{8}\right)$. Anal. Calcd (\%) for $\mathrm{C}_{20} \mathrm{H}_{22} \mathrm{~N}_{4}$ (318.42): $\mathrm{C}$, 75.44; H, 6.96; N, 17.60. Found: C, 75.43; H, 6.93; N, 17.64 .<smiles>CN(C)c1ccc(N(c2ccc(N)cc2)c2ccc(N)cc2)cc1</smiles>

Polymer Synthesis. The synthesis of polyamide $\mathbf{4 b}$ was used as an example to illustrate the general synthetic route used to produce the polyamides. A mixture of $0.318 \mathrm{~g}(1.0 \mathrm{mmol})$ of the $\left(\mathrm{NMe}_{2}\right)$ TPA-diamine monomer 2, $0.258 \mathrm{~g}(1.0 \mathrm{mmol})$ of 4,4'oxidibenzoic acid (3b), $0.1 \mathrm{~g}$ of calcium chloride, $1.0 \mathrm{~mL}$ of triphenyl phosphite (TPP), $0.5 \mathrm{~mL}$ of pyridine, and $2.0 \mathrm{~mL}$ of $\mathrm{N}$-methyl-2-pyrrolidinone (NMP) was heated with stirring at 110 ${ }^{\circ} \mathrm{C}$ for $3 \mathrm{~h}$. The obtained polymer solution was poured slowly into $300 \mathrm{~mL}$ of stirred methanol giving rise to a stringy, fiberlike precipitate that was collected by filtration, washed thoroughly with hot water and methanol, and dried under vacuum at $100{ }^{\circ} \mathrm{C}$. Reprecipitations of the polymer by $\mathrm{N}, \mathrm{N}$-dimethylacetamide (DMAc)/ methanol were carried out twice for further purification. The inherent viscosity of the obtained polyamide $4 \mathbf{b}$ was $1.64 \mathrm{dL} / \mathrm{g}$, measured at a concentration of $0.5 \mathrm{~g} / \mathrm{dL}$ in DMAc at $30^{\circ} \mathrm{C}$.

Preparation of the Polyamide Films. A solution of polymer was made by dissolving about $0.5 \mathrm{~g}$ of the polyamide sample in $10 \mathrm{~mL}$ of DMAc. The homogeneous solution was poured into a 9 $\mathrm{cm}$ glass Petri dish, which was placed in a $90{ }^{\circ} \mathrm{C}$ oven for $5 \mathrm{~h}$ to remove most of the solvent; then the semidried film was further dried in vacuo at $180{ }^{\circ} \mathrm{C}$ for $8 \mathrm{~h}$. The obtained films were about $30-50 \mu \mathrm{m}$ in thickness and were used for X-ray diffraction measurements, solubility tests, and thermal analyses.

Measurements. Elemental analyses were run in a Heraeus VarioEL-III CHNS elemental analyzer. Infrared spectra were recorded on a Horiba FT-720 FT-IR spectrometer. ${ }^{1} \mathrm{H}$ and ${ }^{13} \mathrm{C}$ NMR spectra were measured on a $500 \mathrm{MHz}$ Bruker spectrometer in DMSO- $d_{6}$, using tetramethylsilane as an internal reference. The inherent viscosities were determined at $0.5 \mathrm{~g} / \mathrm{dL}$ concentration using a Cannon-Fenske viscometer at $30^{\circ} \mathrm{C}$. Wide-angle X-ray diffraction (WAXD) measurements were performed at room temperature (ca. $\left.25^{\circ} \mathrm{C}\right)$ on a Shimadzu XRD-6000 X-ray diffractometer $(40 \mathrm{kV}, 20$ $\mathrm{mA}$ ), using graphite-monochromatized $\mathrm{Cu} \mathrm{K} \alpha$ radiation. Thermogravimetric analysis (TGA) was conducted with a PerkinElmer Pyris 1 TGA. Experiments were carried out on approximately $6-8 \mathrm{mg}$ film samples heated in flowing nitrogen or air (flow rate $=20 \mathrm{~cm}^{3}$ / $\min$ ) at a heating rate of $20^{\circ} \mathrm{C} / \mathrm{min}$. DSC analyses were performed on a PerkinElmer Pyris $1 \mathrm{DSC}$ at a scan rate of $20^{\circ} \mathrm{C} / \mathrm{min}$ in flowing nitrogen $\left(20 \mathrm{~cm}^{3} / \mathrm{min}\right)$. Cyclic voltammetry $(\mathrm{CV})$ was performed with a Bioanalytical System Model CV-27 potentiostat, and a BAS $\mathrm{X}-\mathrm{Y}$ recorder with ITO (polymer films area about $0.7 \mathrm{~cm} \times 0.5$ $\mathrm{cm}$ ) was used as a working electrode with a platinum wire as an auxiliary electrode at a scan rate of $50 \mathrm{mV} / \mathrm{s}$ against a $\mathrm{Ag} / \mathrm{AgCl}$ reference electrode in acetonitrile $\left(\mathrm{CH}_{3} \mathrm{CN}\right.$, anhydrous) solution of $0.1 \mathrm{M}$ tetrabutylammonium perchlorate (TBAP) under a nitrogen atmosphere for oxidation measurements. Voltammograms are 
Scheme 1

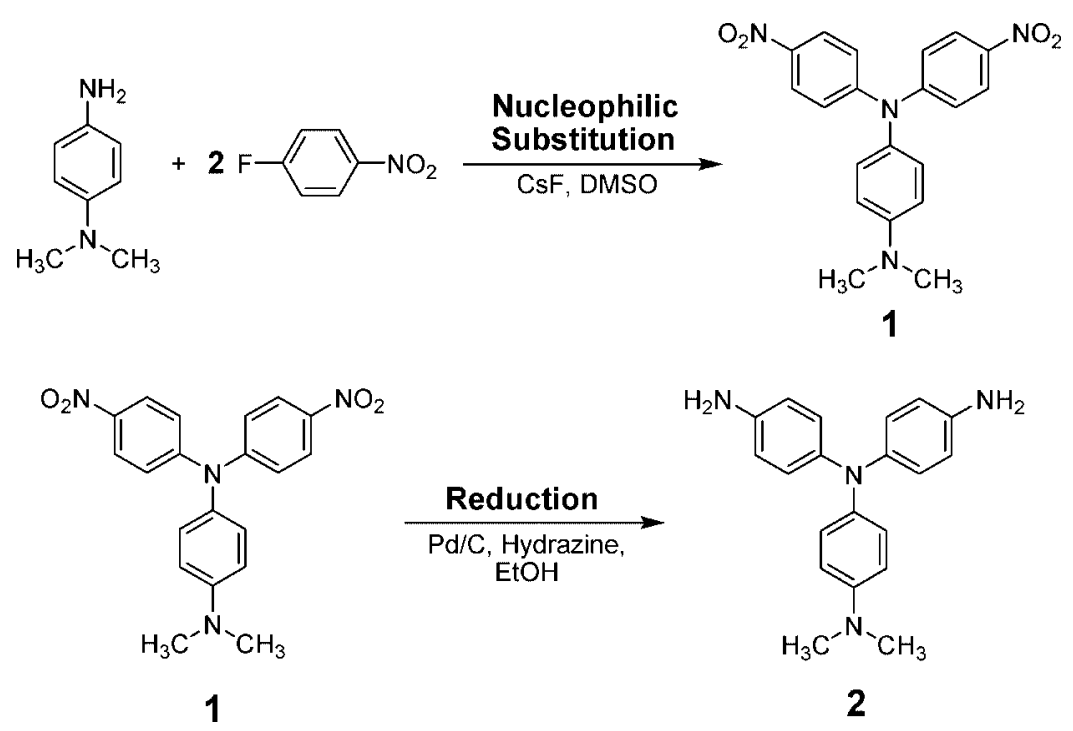

presented with the positive potential pointing to the right and with increasing anodic currents pointing upward. Spectroelectrochemical experiments were carried out in a cell built from a commercial UV-visible cuvette using a Hewlett-Packard 8453 UV-visible diode array spectrophotometer. The ITO-coated glass slide was used as the working electrode, a platinum wire as the counter electrode, and a $\mathrm{Ag} / \mathrm{AgCl}$ cell as the reference electrode.

\section{Results and Discussion}

Monomer Synthesis. The new $\left(\mathrm{NMe}_{2}\right) \mathrm{TPA}$-diamine monomer 2 was synthesized by hydrazine $\mathrm{Pd} / \mathrm{C}$-catalyzed reduction of the dinitro compound $\mathbf{1}$ resulting from the CsF-promoted, aromatic fluoro displacement reaction ${ }^{18}$ of 4-fluoronitrobenzene by $N, N$-dimethyl-p-phenylenediamine (Scheme 1). Elemental

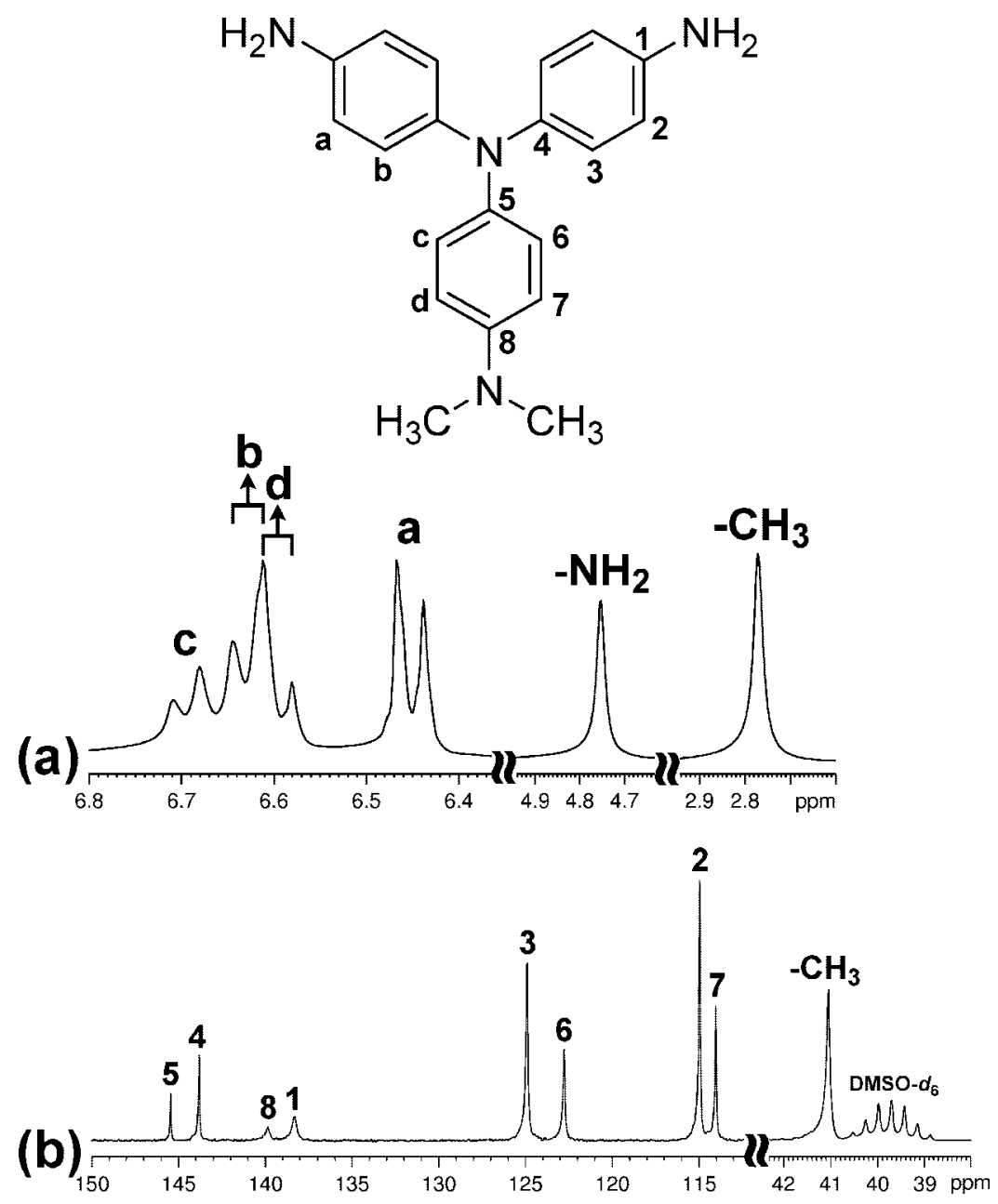

Figure 1. (a) ${ }^{1} \mathrm{H}$ NMR and (b) ${ }^{13} \mathrm{C}$ NMR spectra of (NMe) ${ }_{2}$ TPA-diamine monomer 2 in DMSO- $d_{6}$. 
Scheme 2<smiles>CN(C)c1ccc(N(c2ccc(N)cc2)c2ccc(N)cc2)cc1</smiles>

2<smiles>CN(C)c1ccc(N(c2ccc(NC(=O)[Al]C(C)(C)C)cc2)c2ccc(NC3(C)CC3)cc2)cc1</smiles>

Ar:

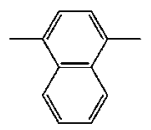

a

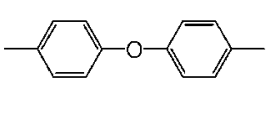

b

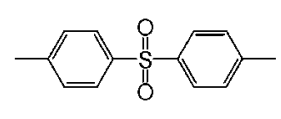

C

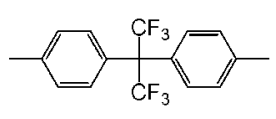

d

Table 1. Inherent Viscosity, Film Color, and Solubility Behavior of Polyamides

\begin{tabular}{|c|c|c|c|c|c|c|c|c|c|}
\hline \multicolumn{3}{|c|}{ polymer } & \multicolumn{7}{|c|}{ solubility in various solvents $^{d}$} \\
\hline code & $\begin{array}{c}\eta_{\text {inh }}{ }^{b} \\
(\mathrm{dL} / \mathrm{g})\end{array}$ & $\begin{array}{c}\text { color of } \\
\text { film }\end{array}$ & NMP & DMAc & $\mathrm{DMF}$ & DMSO & $m$-cresol & $\mathrm{THF}$ & chloroform \\
\hline $4 \mathbf{a}$ & 1.13 & & ++ & ++ & ++ & ++ & ++ & - & +- \\
\hline $4 b$ & 1.64 & & ++ & ++ & ++ & ++ & ++ & - & +- \\
\hline $4 c$ & 0.89 & & ++ & ++ & ++ & ++ & ++ & - & +- \\
\hline $4 d$ & 0.77 & & ++ & ++ & ++ & ++ & ++ & - & +- \\
\hline 4'b & 0.53 & & ++ & ++ & + & ++ & + & - & - \\
\hline 4'c & 0.53 & & ++ & ++ & ++ & ++ & + & - & - \\
\hline
\end{tabular}

${ }^{a}$ Structures of the polymers:

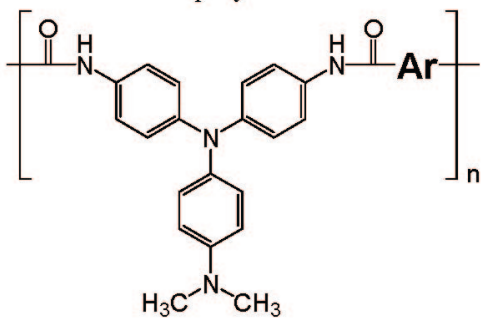

4

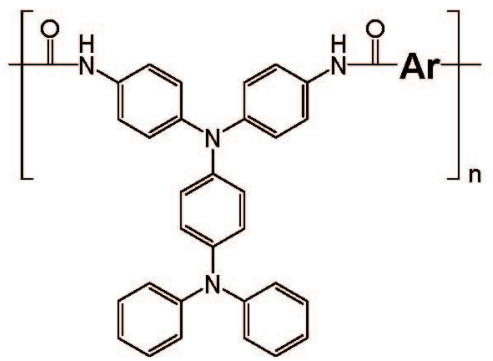

$4^{\prime}$

${ }^{b}$ Measured at a polymer concentration of $0.5 \mathrm{~g} / \mathrm{dL}$ in DMAc- $5 \mathrm{wt} \% \mathrm{LiCl}$ at $30{ }^{\circ} \mathrm{C}$.

${ }^{c}$ The photographs are the appearance of the polymer films (thickness: $1 \sim 3 \mu \mathrm{m}$ ).

${ }^{d}$ The solubility was determined with a $1 \mathrm{mg}$ sample in $1 \mathrm{~mL}$ of a solvent. ++, soluble at room temperature; +, soluble on heating; +-, partially soluble or swelling; - , insoluble even on heating.

analysis, IR, and ${ }^{1} \mathrm{H}$ and ${ }^{13} \mathrm{C}$ NMR spectroscopic techniques were used to identify structures of the intermediate dinitro compound $\mathbf{1}$ and the targeted diamine monomer 2 . The FT-IR spectra of these two synthesized compounds are illustrated in Figure S1 in Supporting Information. The nitro groups of compound 1 gave two characteristic bands at around 1577 and $1340 \mathrm{~cm}^{-1}$ (-NO $\mathrm{NO}_{2}$ asymmetric and symmetric stretching). After reduction, the characteristic absorptions of the nitro group disappeared and the primary amino group showed the typical absorption pair at 3417 and $3340 \mathrm{~cm}^{-1}$ due to $\mathrm{N}-\mathrm{H}$ stretching. ${ }^{1} \mathrm{H}$ NMR and ${ }^{13} \mathrm{C}$ NMR spectra of the diamine monomer $\mathbf{2}$ are illustrated in Figure 1 and agree well with the proposed molecular structure.

Polymer Synthesis. According to the phosphorylation technique first described by Yamazaki and co-workers, ${ }^{19}$ a series of novel polyamides $\mathbf{4 a}-\mathbf{4 d}$ with main-chain $\left(\mathrm{NMe}_{2}\right)$ TPA units were synthesized from the diamine monomer $\mathbf{2}$ with four aromatic dicarboxylic acids $\mathbf{3 a} \mathbf{- 3 d}$ (Scheme 2). The polymerization was carried out via solution polycondensation using triphenyl phosphite and pyridine as condensing agents. All polymerization reactions proceeded smoothly and gave high molecular weights. The obtained polyamides had inherent 


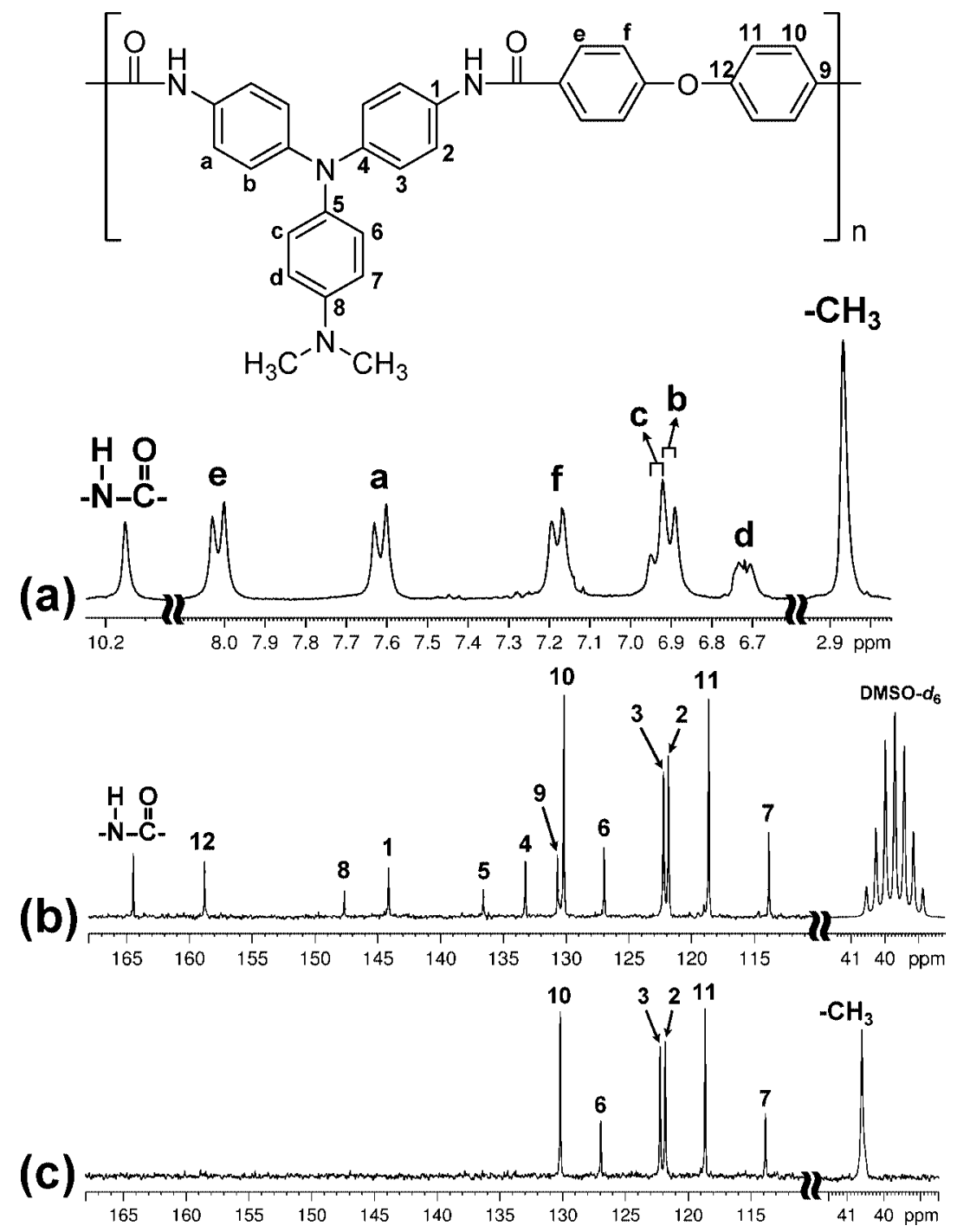

Figure 2. (a) ${ }^{1} \mathrm{H}$ NMR, (b) ${ }^{13} \mathrm{C}$ NMR, and (c) ${ }^{13} \mathrm{C}$ DEPT-135 spectra of polyamide $4 \mathbf{b}$ in DMSO- $d_{6}$.

Table 2. Thermal Properties of Polyamides ${ }^{a}$

\begin{tabular}{|c|c|c|c|c|c|c|}
\hline \multirow{2}{*}{$\begin{array}{l}\text { polymer } \\
\text { code }^{b}\end{array}$} & \multirow[b]{2}{*}{$T_{\mathrm{g}}^{b}\left({ }^{\circ} \mathrm{C}\right)$} & \multicolumn{2}{|c|}{$\begin{array}{c}T_{\mathrm{d}} \text { at } 5 \mathrm{wt} \% \\
\operatorname{loss}^{c}\left({ }^{\circ} \mathrm{C}\right)\end{array}$} & \multicolumn{2}{|c|}{$\begin{array}{c}T_{\mathrm{d}} \text { at } 10 \mathrm{wt} \% \\
\operatorname{loss}^{c}\left({ }^{\circ} \mathrm{C}\right)\end{array}$} & \multirow{2}{*}{$\begin{array}{c}\text { char yield }{ }^{d} \\
(\%)\end{array}$} \\
\hline & & $\mathrm{N}_{2}$ & air & $\mathrm{N}_{2}$ & air & \\
\hline $4 a$ & 283 & 492 & 466 & 525 & 524 & 72 \\
\hline $4 b$ & 277 & 514 & 491 & 569 & 554 & 72 \\
\hline $4 c$ & 295 & 475 & 485 & 514 & 527 & 71 \\
\hline $4 d$ & 298 & 504 & 520 & 566 & 576 & 67 \\
\hline $4 b^{\prime}$ & 263 & 504 & 502 & 546 & 537 & 71 \\
\hline $4 c^{\prime}$ & 287 & 486 & 489 & 549 & 551 & 67 \\
\hline
\end{tabular}

${ }^{a}$ The polymer film samples were heated at $300{ }^{\circ} \mathrm{C}$ for $1 \mathrm{~h}$ prior to all the thermal analyses. ${ }^{b}$ Midpoint temperature of baseline shift on the heating DSC trace (from 50 to 400 at $20{ }^{\circ} \mathrm{C} / \mathrm{min}$ ). ${ }^{c}$ Decomposition temperature at which a $5 \%$ or $10 \%$ weight loss was recorded by TGA at a heating rate of $20^{\circ} \mathrm{C} / \mathrm{min}$ and a gas flow rate of $20 \mathrm{~cm}^{3} / \mathrm{min} .{ }^{d}$ Residual weight percentages at $800{ }^{\circ} \mathrm{C}$ under nitrogen flow.

viscosities in the range of $0.77-1.64 \mathrm{dL} / \mathrm{g}$, as shown in Table 1. All the polymers could afford transparent and tough films via solution casting, indicating high molecular weights. The structures of the polyamides could be confirmed by IR and NMR spectroscopy. A typical IR spectrum for polyamide $\mathbf{4 a}$ is given in Figure S2 in Supporting Information. The characteristic IR absorption bands of the amide group appeared at around 3280 $\mathrm{cm}^{-1}$ (N-H stretch) and $1657 \mathrm{~cm}^{-1}$ (amide carbonyl). ${ }^{1} \mathrm{H} \mathrm{NMR}$ and ${ }^{13} \mathrm{C}$ NMR spectra of polyamide $\mathbf{4 b}$ are illustrated in Figure 2. Assignments of each proton and carbon are also given in the figure, and these spectra agree well with the proposed polymer

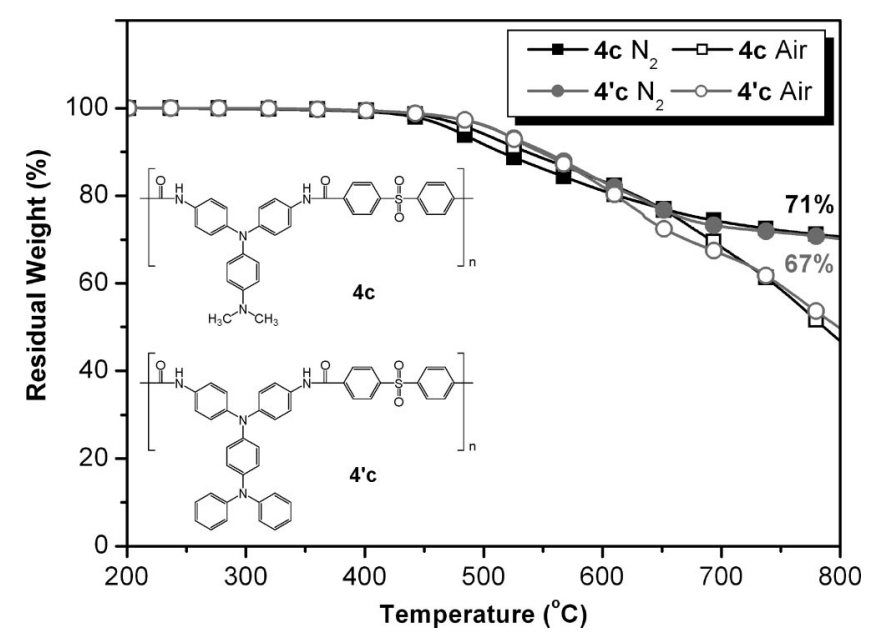

Figure 3. TGA thermograms of polyamides $\mathbf{4 c}$ and $\mathbf{4} \mathbf{c}^{\prime}$ at a scan rate of $20^{\circ} \mathrm{C} / \mathrm{min}$.

structure. Two structurally related polyamides $\mathbf{4 b}^{\prime}$ and $\mathbf{4} \mathbf{c}^{\prime}$ derived from $\left(\mathrm{NPh}_{2}\right) \mathrm{TPA}$-diamine $\mathbf{2}^{\prime}$ are used for comparison studies. The synthesis and characterization of polymers $\mathbf{4} \mathbf{b}^{\prime}$ and $\mathbf{4} \mathbf{c}^{\prime}$ have been described previously. ${ }^{13 \mathrm{~b}}$

Solubility and Film Property. The solubility properties of polymers $\mathbf{4 a}-\mathbf{4 d}$ were investigated qualitatively, and the results 


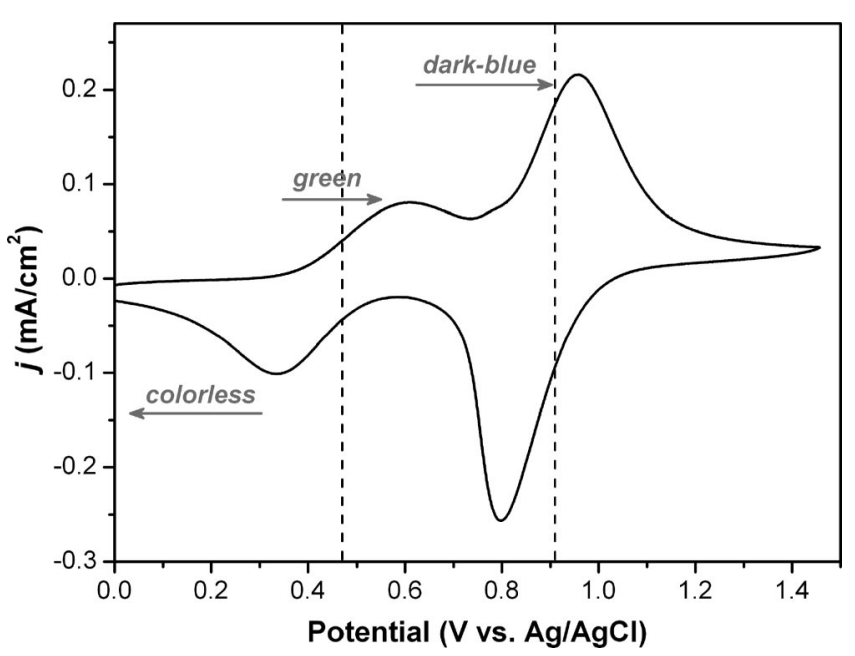

Figure 4. Cyclic voltammetric diagrams of the polyamide $4 \mathbf{b}$ film on an ITO-coated glass substrate in $\mathrm{CH}_{3} \mathrm{CN}$ solutions containing $0.1 \mathrm{M}$ TBAP at a scan rate of $50 \mathrm{mV} / \mathrm{s}$. The arrows indicate the film color change during $\mathrm{CV}$ scan. $E_{1 / 2}$ values are indicated by dashed lines.

are also listed in Table 1. All the polyamides were readily soluble in polar aprotic organic solvents such as NMP, DMAc, DMF, and DMSO. Thus, the excellent solubility makes these polymers potential candidates for practical applications by spincoating or inkjet-printing processes to afford high performance thin films for optoelectronic devices. As mentioned earlier, the polyamides $\mathbf{4 a}-\mathbf{4 d}$ could be solvent cast into flexible, transpar- ent, and tough films. As shown in Table 1, the cast films are transparent gray (for 4b), light yellowish green (for $\mathbf{4 a}$ and $\mathbf{4 d}$ ), and pale brown (for $\mathbf{4 c}$ ) in color. The WAXD studies of these film samples indicated that all the polymers were essentially amorphous (see Figure S3 in Supporting Information). Their high solubility and amorphous properties can be attributed to the incorporation of bulky, three-dimensional $\left(\mathrm{NMe}_{2}\right) \mathrm{TPA}$ moiety along the polymer backbone, which results in a high steric hindrance for close packing, and thus reduces their crystallization tendency.

Thermal Properties. The thermal properties of polyamides were examined by TGA and DSC, and the thermal behavior data are summarized in Table 2. Typical TGA curves of representative polyamides $\mathbf{4} \mathbf{c}$ and $\mathbf{4}^{\prime} \mathbf{c}$ in both air and nitrogen atmospheres are shown in Figure 3. Even with the introduction of $\mathrm{NMe}_{2}$ groups, all prepared polyamides exhibited good thermal stability with insignificant weight loss up to $450{ }^{\circ} \mathrm{C}$ under nitrogen or air atmosphere. The $10 \%$ weight loss temperatures of these polymers in nitrogen and air were recorded in the range of 514-566 and $527-576{ }^{\circ} \mathrm{C}$, respectively. The concentration of carbonized residue (char yield) of these polymers in a nitrogen atmosphere was more than $67 \%$ at $800{ }^{\circ} \mathrm{C}$. The high char yields of these polymers can be ascribed to their high aromatic content. The glass-transition temperatures $\left(T_{\mathrm{g}}\right)$ of polyamides $\mathbf{4 a}-\mathbf{4 d}$ could be easily measured in the DSC thermograms; they were observed in the range of $277-298{ }^{\circ} \mathrm{C}$, depending upon the stiffness of the polymer chain. The lowest $T_{\mathrm{g}}$ value of $\mathbf{4 b}$ in this series polymers can be explained in terms of the flexible ether linkage in its diacid component. All the

Scheme 3

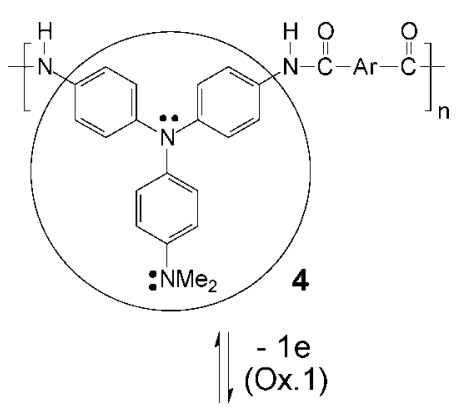

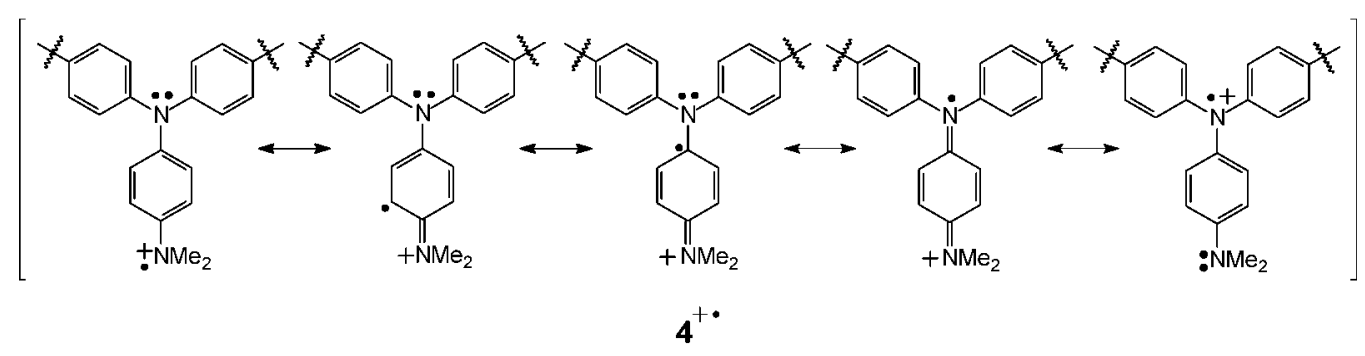

(a cation radical)

$$
\| \begin{gathered}
-1 \mathrm{e} \\
(\mathrm{Ox} .2)
\end{gathered}
$$<smiles>Cc1ccc(N(c2ccc(C)cc2)c2ccc(N(C)C)cc2)cc1</smiles> 
Table 3. Redox Potentials and Energy Levels of Polyamides

\begin{tabular}{|c|c|c|c|c|c|c|c|c|}
\hline \multirow[b]{3}{*}{ polymer } & & & \multicolumn{3}{|c|}{ oxidation potential (V) (vs $\mathrm{Ag} / \mathrm{AgCl}$ in $\mathrm{CH}_{3} \mathrm{CN}$} & \multirow[b]{3}{*}{$E_{\mathrm{g}}{ }^{b}(\mathrm{eV})$} & \multirow[b]{3}{*}{$\mathrm{HOMO}^{c}(\mathrm{eV})$} & \multirow[b]{3}{*}{ LUMO $(\mathrm{eV})$} \\
\hline & \multicolumn{2}{|c|}{ UV-vis absorption of the polymer films (nm) } & \multicolumn{2}{|c|}{$E_{1 / 2}{ }^{a}$} & \multirow[b]{2}{*}{$E_{\text {onset }}$} & & & \\
\hline & $\lambda_{\max }$ & $\lambda_{\text {onset }}$ & first & second & & & & \\
\hline 4b & 343 & 440 & 0.47 & 0.91 & 0.38 & 2.82 & 4.74 & 1.92 \\
\hline $4 c$ & 320 & 490 & 0.41 & 0.91 & 0.37 & 2.53 & 4.73 & 2.20 \\
\hline $4 d$ & 346 & 454 & 0.45 & 0.91 & 0.35 & 2.73 & 4.71 & 1.98 \\
\hline $4 b^{\prime}$ & 348 & 398 & 0.63 & 1.00 & 0.53 & 2.95 & 4.89 & 1.94 \\
\hline
\end{tabular}

${ }^{a} E_{1 / 2}$ (average potential of the redox couple peaks). ${ }^{b}$ The data were calculated from polymer films by the equation $E_{\mathrm{g}}=1240 / \lambda_{\text {onset }}$ (energy gap between HOMO and LUMO). ${ }^{c}$ The HOMO energy levels were calculated from cyclic voltammetry and were referenced to ferrocene (4.8 eV).

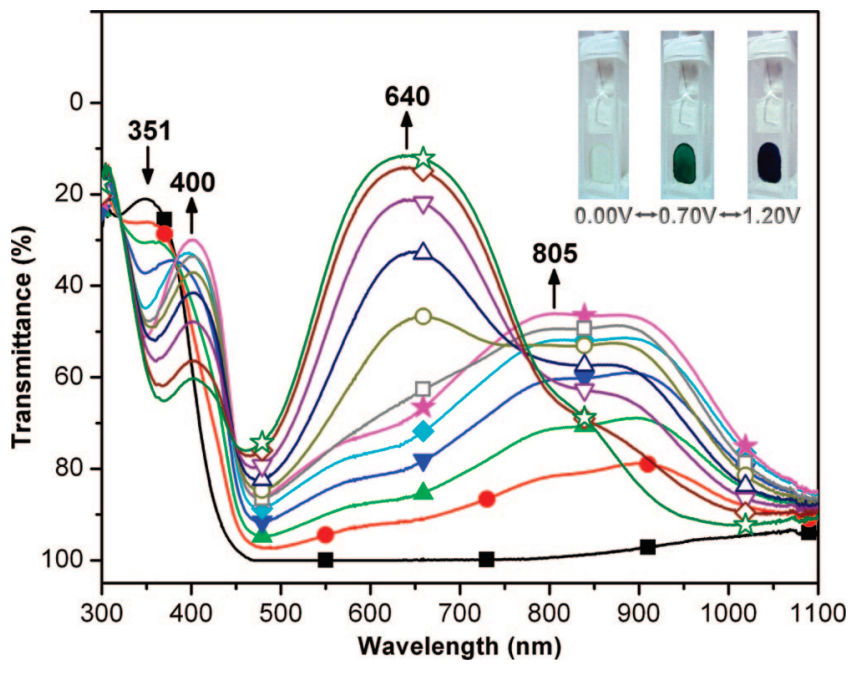

Figure 5. Spectral change of $\mathbf{4 b}$ thin film on the ITO-coated glass substrate (in $\mathrm{CH}_{3} \mathrm{CN}$ with $0.1 \mathrm{M}$ TBAP as the supporting electrolyte) along with increasing of the applied voltage: $0(\mathbf{\square}), 0.40(\mathbf{\bullet}), 0.50(\mathbf{\Delta})$, $0.55(\boldsymbol{\nabla}), 0.60(\diamond), 0.70(\star), 0.80(\square), 0.90(\bigcirc), 0.95(\Delta), 1.00(\nabla)$, $1.10(\diamond)$, and $1.20 \mathrm{~V}(\square) \mathrm{vs} \mathrm{Ag} / \mathrm{AgCl}$ couple as reference. The inset shows the photographic images of the film at indicated applied voltages.

polymers indicated no clear melting endotherms up to the decomposition temperatures on the DSC thermograms. This result supports the amorphous nature of these polyamides. As can be seen from Table 2 , polyamides $\mathbf{4 b}$ and $\mathbf{4 c}$ revealed a slightly higher $T_{\mathrm{g}}$ as compared to their respective analogs $\mathbf{4} \mathbf{b}^{\prime}$ and $\mathbf{4} \mathbf{c}^{\prime}$. This result implies that the bulky $\mathrm{NPh}_{2}$ substituent in the $4^{\prime}$ series polyamides leads to an increase in steric hindrance for close chain packing, as well as an enhanced fractional free volume between polymer chains.

Electrochemical Properties. The electrochemical properties of the polyamides were investigated by cyclic voltammetry (CV) conducted for the cast film on an ITO-coated glass slide as working electrode in anhydrous acetonitrile $\left(\mathrm{CH}_{3} \mathrm{CN}\right)$, using 0.1 $\mathrm{M}$ of TBAP as a supporting electrolyte under a nitrogen atmosphere. Figure 4 displays the first CV scan of polyamide 4b; we observe two reversible redox steps at the half-wave oxidation potential $\left(E_{1 / 2}\right)$ of 0.45 and $0.91 \mathrm{~V}$, respectively. When comparing the first and second oxidation steps, the first oxidation step exhibited smaller anodic and cathodic currents and larger difference between $E_{\mathrm{pa}}$ and $E_{\mathrm{pc}}\left(\Delta E_{\mathrm{p}}=0.29 \mathrm{~V}\right)$ than the second step $\left(\Delta E_{\mathrm{p}}=0.16 \mathrm{~V}\right)$. It could be attributed to the lower heterogeneous electron transfer rate of first oxidation step. ${ }^{20}$ The color of the film changed from colorless to green and then to deep blue because of electrochemical oxidation of the polymer. The oxidative and electrochromic reversibility of polymer $\mathbf{4 b}$ is maintained on repeated scanning between 0 and $1.4 \mathrm{~V}$ (vs $\mathrm{Ag} / \mathrm{AgCl}$ ). This result confirms that para-substitution of the $\mathrm{NMe}_{2}$ group on the TPA unit lends considerable stability to both the cation radical and dication quinonediimine species, as shown in Scheme 3. The other polyamides showed similar CV curves to that of $\mathbf{4 b}$. The redox potentials of the various polyamides as well as their respective HOMO and LUMO potentials (vs vacuum) are shown in Table 3. It is also worth noting that polyamide $\mathbf{4 b}$ reveals a lower onset oxidation potential $\left(E_{\text {onset }}\right)(0.38 \mathrm{~V})$ compared to its analog $4 \mathbf{b}^{\prime}\left(E_{\text {onset }}=\right.$ $0.53 \mathrm{~V}$ ) with an $\mathrm{NPh}_{2}$ substituent on the TPA unit. This indicates that the first oxidation wave in the $\mathrm{CV}$ curve of polyamide $\mathbf{4 b}$ is attributed to its $\mathrm{NMe}_{2}$ groups. As shown in Table 3, the HOMO level or called ionization potentials (vs vacuum) of polyamides $\mathbf{4 a}-\mathbf{4 d}$ are estimated from the onset of their oxidation in $\mathrm{CV}$ experiments as $4.68-4.74 \mathrm{eV}$ (on the basis that ferrocene/ferrocenium is $4.8 \mathrm{eV}$ below the vacuum level). The lower ionization potential could suggest an easier hole injection into films from ITO electrodes in electronic device applications. Traditionally, introduction of TPA units in conjugated polymers or organic molecules was found to effectively enhance the holeinjecting properties of the resulting materials. ${ }^{21}$

Spectroelectrochemical and Electrochromic Characteristics. Following the electrochemical tests, the optical properties of the electrochromic films were evaluated by using spectroelectrochemistry. For these investigations, the polyamide film was cast on an ITO-coated glass slide (a piece that fit in the commercial UV-visible cuvette), and a homemade electrochemical cell was built from a commercial UV-visible cuvette. The cell was placed in the optical path of the sample light beam in a commercial diode array spectrophotometer. This procedure allowed us to obtain electronic absorption spectra under potential control in a $0.1 \mathrm{M}$ TBAP/MeCN solution. The result of the $\mathbf{4 b}$ film is presented in Figure 5 as a series of UV-vis absorbance curves correlated to electrode potentials. Figure 6 shows the three-dimensional \% transmittance-wavelength-applied potential correlations of this sample. In the neutral form, at $0 \mathrm{~V}$, the film exhibited strong absorption at wavelength around $350 \mathrm{~nm}$, characteristic for triarylamine, but it was almost transparent in the visible region. Upon oxidation of the $\mathbf{4 b}$ film (increasing applied voltage from 0 to $0.7 \mathrm{~V}$ ), the intensity of the absorption peak at $351 \mathrm{~nm}$ gradually decreased while a new peak at 400 $\mathrm{nm}$ and a broadband having its maximum absorption wavelength at $805 \mathrm{~nm}$ gradually increased in intensity. We attribute this spectral change to the formation of a stable monocation radical of the $\left(\mathrm{NMe}_{2}\right) \mathrm{TPA}$ moiety. As the applied potential became more anodic to $1.2 \mathrm{~V}$, the absorption bands of the cation radical decreased gradually in intensity, with the formation of a new broadband centered at around $640 \mathrm{~nm}$. This spectral change can be attributable to the formation of a dication in the $\left(\mathrm{NMe}_{2}\right) \mathrm{TPA}$ segment of the polyamide. The observed UV-vis absorption changes in the film of $\mathbf{4 b}$ at various potentials are fully reversible and are associated with strong color changes; indeed, they even can be seen readily by the naked eye. From the inset shown in Figure 5, it can be seen that the film of $\mathbf{4 b}$ switches from a transmissive neutral state (colorless) to a highly absorbing semioxidized state (green) and a fully oxidized state (deep blue). The film colorations are distributed homogeneously across the 


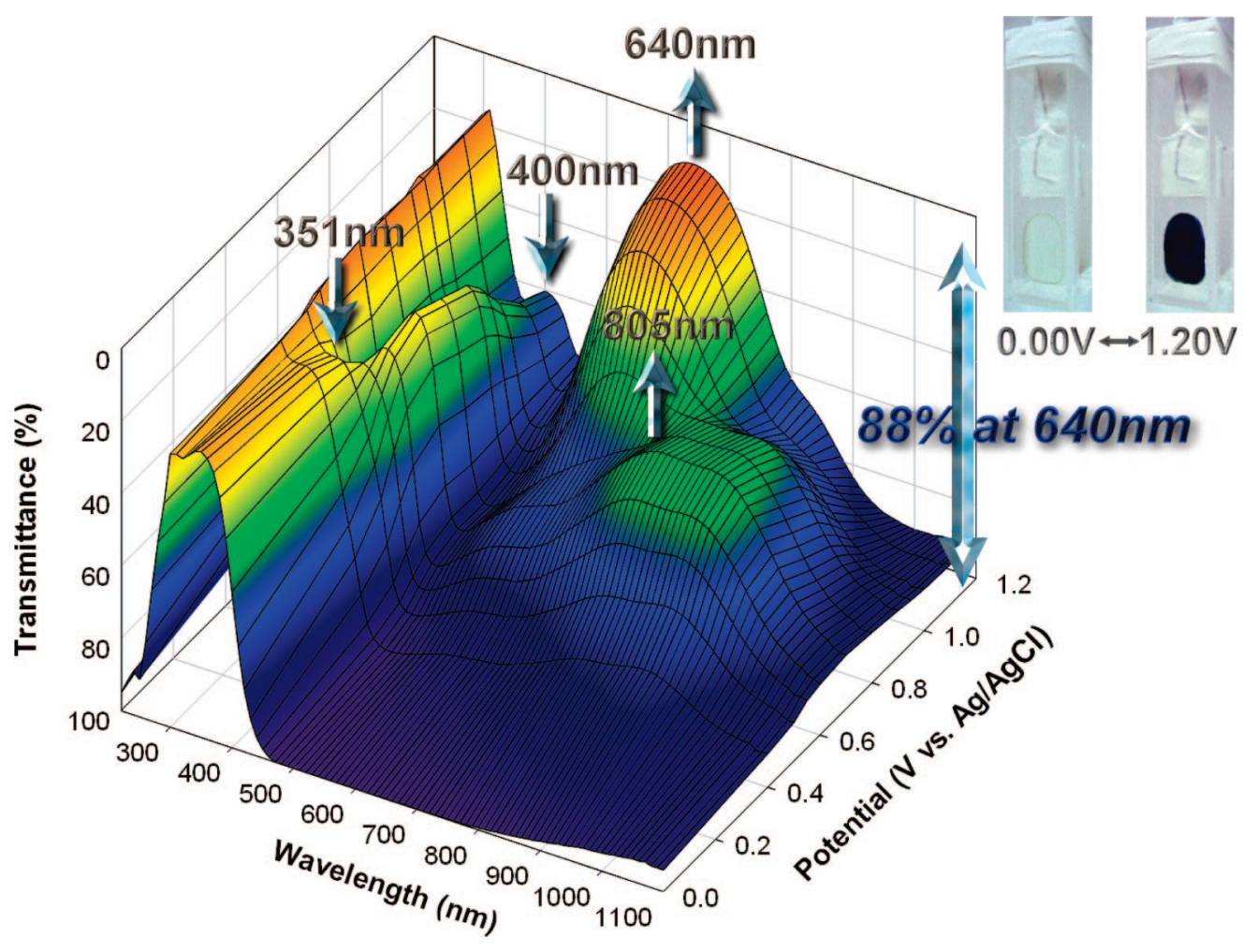

Figure 6. 3-D spectroelectrochemical behavior of the $\mathbf{4 b}$ thin film on the ITO-coated glass substrate (in $\mathrm{CH}_{3} \mathrm{CN}$ with $0.1 \mathrm{M}$ TBAP as the supporting electrolyte from 0 to $1.2 \mathrm{~V}$ ( $\mathrm{vs} \mathrm{Ag} / \mathrm{AgCl}$ ).

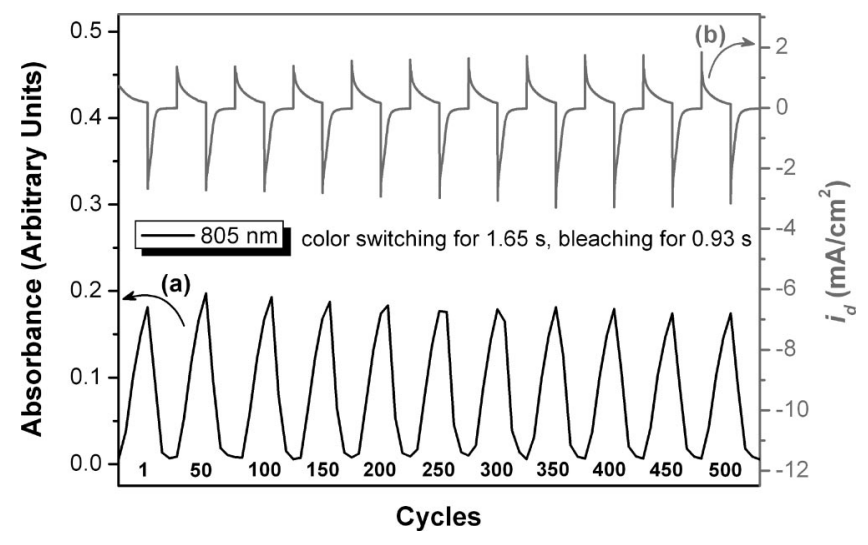

Figure 7. (a) Potential step absorptometry and (b) current consumption of the polyamide $\mathbf{4 b}$ film on to the ITO-coated glass substrate (coated area $=1 \mathrm{~cm}^{2}$ ) during the continuous cycling test by switching potentials between 0 and $0.55 \mathrm{~V}$ (vs $\mathrm{Ag} / \mathrm{AgCl}$ ).

polymer film and survive for more than hundreds of redox cycles. The polymer $\mathbf{4 b}$ shows good contrast in the visible region, with an extremely high optical transmittance change $(\Delta \% \mathrm{~T})$ of $88 \%$ at $\lambda_{\max }=640 \mathrm{~nm}$, comparable to that obtained in conducting poly(3,4-dialkylenedioxythiophene) derivatives. ${ }^{14}$ The coloration efficiency at $640 \mathrm{~nm}$ is as high as ca. $261 \mathrm{~cm}^{2} / \mathrm{C}$ with a high optical density change $(\delta \mathrm{OD})$ up to 0.94 , determined from the in situ experiments. Because of the apparent high electrochromic contrast in the spectroelectrochemistry, optical switching studies were performed to more deeply probe the polymer's electrochromic properties.

For optical switching studies, polymer films were cast on ITOcoated glass slides in the same manner as described above, and each film was potential stepped between its neutral $(0 \mathrm{~V})$ and oxidized $(+0.55 \mathrm{~V})$ state. While the films were switched, the absorbance at $805 \mathrm{~nm}$ was monitored as a function of time with UV-vis-near-IR spectroscopy. Switching data for the cast film
Table 4. Coloration Efficiency of Polyamide 4b

\begin{tabular}{ccccc}
\hline cycles $^{a}$ & $\delta \mathrm{OD}_{805}{ }^{b}$ & $Q^{c}\left(\mathrm{mC} / \mathrm{cm}^{2}\right)$ & $\eta^{d}\left(\mathrm{~cm}^{2} / \mathrm{C}\right)$ & decay $^{e}(\%)$ \\
\hline 1 & 0.176 & 0.727 & 242 & 0 \\
50 & 0.191 & 0.802 & 238 & 1.7 \\
100 & 0.185 & 0.797 & 232 & 4.1 \\
150 & 0.182 & 0.801 & 227 & 6.2 \\
200 & 0.176 & 0.796 & 221 & 8.7 \\
250 & 0.168 & 0.770 & 218 & 9.9 \\
300 & 0.169 & 0.793 & 213 & 12.0 \\
350 & 0.176 & 0.842 & 209 & 13.6 \\
400 & 0.173 & 0.848 & 204 & 15.7 \\
450 & 0.168 & 0.848 & 198 & 18.2 \\
500 & 0.168 & 0.870 & 193 & 20.2
\end{tabular}

${ }^{a}$ Times of cyclic scan by applying potential steps: $0.00 \leftrightarrow 0.55 \mathrm{~V}$ (vs $\mathrm{Ag} / \mathrm{AgCl}) .{ }^{b}$ Optical density change at $805 \mathrm{~nm} .{ }^{c}$ Ejected charge, determined from the in situ experiments. ${ }^{d}$ Coloration efficiency is derived from the equation: $\eta=\delta \mathrm{OD}_{805} / Q .{ }^{e}$ Decay of coloration efficiency after cyclic scans.

of polyamide $\mathbf{4 b}$ are given in Figure S4 (see Supporting Information). The switching time was calculated at $90 \%$ of the full switch because it is difficult to perceive any further color change with naked eye beyond this point. The polyamides switch rapidly (within $2 \mathrm{~s}$ ) between the highly transmissive neutral state and the colored oxidized state. Thin film of polyamide $\mathbf{4 b}$ required only $1.65 \mathrm{~s}$ at $0.55 \mathrm{~V}$ for coloring and $0.93 \mathrm{~s}$ for bleaching, reflecting the different reaction rates between the neutral and oxidized forms of the film of $\mathbf{4 b}$. As shown in Figure 7, the absorbance changes at $805 \mathrm{~nm}$ reflect the switch in current, and the kinetics of the charge transport process can be referenced to the coloration response time. The electrochromic coloration efficiencies $\left(\eta=\delta \mathrm{OD}_{805} / Q\right)$ after various switching steps of the film of polyamide $\mathbf{4 b}$ are summarized in Table 4 . The electrochromic film of $\mathbf{4 b}$ was found to exhibit high coloration efficiencies up to $242 \mathrm{~cm}^{2} / \mathrm{C}$ at $805 \mathrm{~nm}$, and to retain near $80 \%$ of its optical response after 500 coloring/bleaching cycles. Therefore, the electrochromic switching behavior appears to be a highly reversible process. 


\section{Conclusions}

A new triphenylamine-based aromatic diamine monomer, 4,4'-diamino-4"'-(dimethylamino)triphenylamine, was synthesized in high purity and high yields from readily available reagents. A series of novel 4-(dimethylamino)triphenylamine [(NMe $)$ TPA $]$-functionalized aromatic polyamides were readily prepared from the newly synthesized diamine monomer with various aromatic dicarboxylic acids via the phosphorylation polyamidation reaction. Introduction of extremely electrondonating $\left(\mathrm{NMe}_{2}\right) \mathrm{TPA}$ group to the polymer main chain not only stabilizes triphenylamine cationic radicals and dications but also leads to good solubility and film-forming properties of the polyamides. In addition to high $T_{\mathrm{g}}$ and good thermal stability, all the obtained polymers also reveal valuable electrochromic characteristics such as high contrast (colorless neutral form to oxidized dark blue forms), high coloration efficiency, good electrochromic reversibility and rapid switching times. Thus, these characteristics suggest that these new polyamides have great potential for use in optoelectronics applications.

Acknowledgment. We are grateful to the National Science Council of Taiwan for the financial support.

Supporting Information Available: IR spectra of compounds $\mathbf{1}$ and 2, typical IR spectrum of polymer 4a, WAXD patterns of polyamides, and optical switching data for polyamide $\mathbf{4 b}$. This information is available free of charge via the Internet at http:// pubs.acs.org.

\section{References and Notes}

(1) (a) Monk, P. M. S.; Mortimer, R. J.; Rosseinsky, D. R. Electrochromism: Fundamentals and Applications; VCH: Weinheim, Germany, 1995. (b) Mortimer, R. J. Chem. Soc. Rev. 1997, 26, 147. (c) Monk, P. M. S.; Mortimer, R. J.; Rosseinsky, D. R. Electrochromism and Electrochromic Devices; Cambridge University Press: Cambridge, UK, 2007.

(2) (a) Rosseinsky, D. R.; Montimer, R. J. Adv. Mater. 2001, 13, 783. (b) Cronin, J. P.; Gudgel, T. J.; Kennedy, S. R.; Agrawal, A.; Uhlmann, D. R. Mater. Res. 1999, 2, 1. (c) Cummins, D.; Boschloo, G.; Ryan, M.; Corr, D.; Rao, S. N.; Fitzmaurice, D. J. Phys. Chem. B 2000, 104, 11449. (d) Heuer, H. W.; Wehrmann, R.; Kirchmeyer, S. Adv. Funct. Mater. 2002, 12, 89.

(3) Monk, P. M. S. The Viologens: Synthesis, Physicochemical Properties and Applications of the Salts of 4,4'-Bipyridine; Wiley: Chichester, UK, 1998.

(4) (a) Gao, J.; Liu, D.-G.; Sansinena, J.-M.; Wang, H.-L. Adv. Funct. Mater. 2004, 14, 537. (b) Manisankar, P.; Vedhi, C.; Selvanathan, G.; Somasundaram, R. M. Chem. Mater. 2005, 17, 1722.

(5) (a) Welsh, D. M.; Kumar, A.; Morvant, M. C.; Reynolds, J. R. Synth. Met. 1999, 102, 967. (b) Groenendaal, L.; Zotti, G.; Aubert, P.-H.; Waybright, S. M.; Reynolds, J. R. Adv. Mater. 2003, 15, 855.

(6) (a) Schottland, P.; Zong, K.; Gaupp, C. L.; Thompson, B. C.; Thomas, C. A.; Giurgiu, I.; Hickman, R.; Abboud, K. A.; Reynolds, J. R. Macromolecules 2000, 33, 7051. (b) Zong, K.; Reynolds, J. R. J. Org. Chem. 2001, 66, 6873. (c) Sonmez, G.; Schwendeman, I.; Schottland, P.; Zong, K.; Reynolds, J. R. Macromolecules 2003, 36, 639. (d) Walczak, R. M.; Reynolds, J. R. Adv. Mater. 2006, 18, 1121.

(7) (a) Faughnan, B. W.; Crandall, R. S. In Display Devices; Pankove, J. I. Ed.; Springer-Verlag; Berlin, 1980 Chapter 5. (b) Granqvist, G. V. Phys. Thin Films 1993, 17, 301.

(8) (a) Reeves, B. D.; Thompson, B. C.; Abboud, K. A.; Smart, B. E.; Reynolds, J. R. Adv. Mater. 2002, 14, 717. (b) Argun, A. A.; Aubert, P. H.; Thompson, B. C.; Schwendeman, I.; Gaupp, C. L.; Hwang, J.;
Pinto, N. J.; Tanner, D B.; MacDiarmid, A. G.; Reynolds, J. R. Chem. Mater. 2004, 16, 4401.

(9) (a) Gaupp, C. L.; Reynolds, J. R. Macromolecules 2003, 36, 6305. (b) Reeves, B. D.; Grenier, C. R. G.; Argun, A. A.; Cirpan, A.; McCarley, T. D.; Reynolds, J. R. Macromolecules 2004, 37, 7559. (c) Witker, D.; Reynolds, J. R. Macromolecules 2005, 38, 7636. (d) Thompson, B. C.; Kim, Y.-G.; McCarley, T. D.; Reynolds, J. R. J. Am. Chem. Soc. 2006, 128, 12714.

(10) (a) Sonmez, G.; Meng, H.; Wudl, F. Chem. Mater. 2004, 16, 574. (b) Sonmez, G.; Sonmez, H. B.; Shen, C. K. F.; Wudl, F. Adv. Mater. 2004, 16, 1905. (c) Sonmez, G.; Shen, C. K. F.; Rubin, Y.; Wudl, F. Angew. Chem., Int. Ed. 2004, 43, 1498. (d) Sonmez, G.; Sonmez, H. B.; Shen, C. K. F.; Jost, R. W.; Rubin, Y.; Wudl, F. Macromolecules $2005,38,669$.

(11) (a) Shirota, Y. J. Mater. Chem. 2000, 10, 1. (b) Thelakkat, M. Macromol. Mater. Eng. 2002, 287, 442. (c) Shirota, Y. J. Mater. Chem. 2005, 15, 75 .

(12) (a) Ogino, K.; Kanegae, A.; Yamaguchi, R.; Sato, H.; Kujata, J. Macromol. Rapid Commun. 1999, 20, 103. (b) Leung, M.-k.; Chou, M.-Y.; Su, Y. O.; Chiang, C.-L.; Chen, H.-L.; Yang, C.-F.; Yang, C.-C.; Lin, C.-C.; Chen, H.-T. Org. Lett. 2003, 5, 839. (c) Chou, M.Y.; Leung, M.-k.; Su, Y. O.; Chiang, C.-L.; Lin, C.-C.; Liu, J.-H.; Kuo, C.-K.; Mou, C.-Y. Chem. Mater. 2004, 16, 654. (d) Beaupre, S.; Dumas, J.; Leclerc, M. Chem. Mater. 2006, 18, 4011. (e) Choi, K.; Yoo, S. J.; Sung, Y.-E.; Zentel, R. Chem. Mater. 2006, 18, 5823. (f) Otero, L.; Sereno, L.; Fungo, F.; Liao, Y.-L.; Lin, C.-Y.; Wong, K.-T. Chem. Mater. 2006, 18, 3495. (g) Natera, J.; Otero, L.; Sereno, L.; Fungo, F.; Wang, N.-S.; Tsai, Y.-M.; Hwu, T.-Y.; Wong, K.-T. Macromolecules 2007, 40, 4456.

(13) (a) Cheng, S.-H.; Hsiao, S.-H.; Su, T.-H.; Liou, G.-S. Macromolecules 2005, 38, 307. (b) Su, T.-H.; Hsiao, S.-H.; Liou, G.-S. J. Polym. Sci. Part A: Polym Chem. 2005, 43, 2085. (c) Liou, G.-S.; Hsiao, S.-H.; Su, T.-H. J. Mater. Chem. 2005, 15, 1812. (d) Liou, G.-S.; Hsiao, S.-H.; Chen, H.-W. J. Mater. Chem. 2006, 16, 1831. (e) Liou, G.-S.; Hsiao, S.-H.; Huang, N.-K.; Yang, Y.-L. Macromolecules 2006, 39, 5337. (f) Liou, G.-S.; Hsiao, S.-H.; Chen, W.-C.; Yen, H.-J. Macromolecules 2006, 39, 6036. (g) Chang, C.-W.; Liou, G.-S.; Hsiao, S.H. J. Mater. Chem. 2007, 17, 1007.

(14) (a) Kumar, A.; Welsh, D. M.; Morvant, M. C.; Piroux, F.; Abboud, K. A.; Reynolds, J. R. Chem. Mater. 1998, 10, 896. (b) Sapp, S. A.; Sotzing, G. A.; Reynolds, J. R. Chem. Mater. 1998, 10, 2101. (c) Welsh, D. M.; Kumar, A.; Meijer, E. W.; Reynolds, J. R. Adv. Mater. 1999, 11, 1379. (d) Schwendeman, I.; Hickman, R.; Sonmez, G.; Schottland, P.; Zong, K.; Welsh, D. M.; Reynolds, J. R. Chem. Mater. 2002, 14, 3118.

(15) (a) Seo, E. T.; Nelson, R. F.; Fritsch, J. M.; Marcoux, L. S.; Leedy, D. W.; Adams, R. N. J. Am. Chem. Soc. 1966, 88, 3498. (b) Nelson, R. F.; Adams, R. N. J. Am. Chem. Soc. 1968, 90, 3925.

(16) Zhao, H.; Tanjutco, C.; Thayumanavan, S. Tetrahedron Lett. 2001, $42,4421$.

(17) Ambrose, J. F.; Carpenter, L. L.; Nelson, R. F. J. Electrochem. Soc.: Electrochem. Sci. Technol. 1975, 122, 876.

(18) Oishi, Y.; Takado, H.; Yoneyama, M.; Kakimoto, M.; Imai, Y. J. Polym. Sci. Part A: Polym. Chem. 1990, 28, 1763.

(19) Yamazaki, N.; Matsumoto, M.; Higashi, F. J. Polym. Sci. Polym. Chem. Ed. 1975, 13, 1373.

(20) Bard, A. J.; Faulkner, L. R. Electrochemical Methods: Fundamentals and Applications, 2nd ed.; John Wiley \& Sons: New York, 2001; Chapter 1.3 .

(21) (a) Liu, Y.; Liu, M. S.; Li, X.-C.; Jen, A. K.-Y. Chem. Mater. 1998, 10, 3301. (b) Redecker, M.; Bradley, D. D. C.; Inbasekaran, M.; Wu, W.; Woo, E. P. Adv. Mater. 1999, 11, 241. (c) Pu, Y.-J.; Soma, M.; Kido, J.; Nishi, H. Chem. Mater. 2001, 13, 3817. (d) Ego, C.; Grimsdale, A. C.; Uckert, F.; Yu, G.; Srdanov, G.; Mullen, K. Adv. Mater. 2002, 14, 809. (e) Shu, C.-F.; Dodda, R.; Wu, F.-I.; Liu, M. S.; Jen, A. K.-Y. Macromolecules 2003, 36, 6698. (f) Wu, F.-I.; Shih, P.-I.; Shu, C.-F.; Tung, Y.-L.; Chi, Y. Macromolecules 2005, 38, 9028. (g) Kong, Q.; Zhu, D.; Quan, Y.; Chen, Q.; Ding, J.; Lu, J.; Tao, Y. Chem. Mater. 2007, 19, 3309.

MA702426Z 